\title{
Reflections
}

\section{Envisioning human security - commentary to Gill}

\author{
JOHN MORRISSEY
}

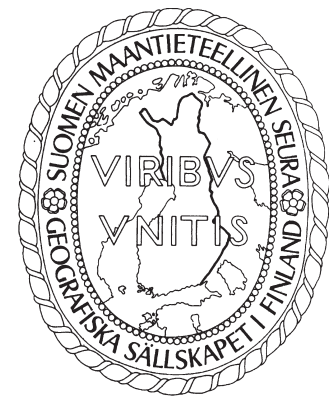

Morrissey, J. (2018) Envisioning human security - commentary to Gill. Fennia 196(2) 225-229. https://doi.org/10.11143/fennia.76029

Prompted by Nick Gill's review essay, 'The suppression of welcome', this commentary additionally reflects on attendant questions of security and responsibility in seeking to conceptualize a more human-centred vision of populations and population management in our current moment of refugee crisis in Europe. It charts how we might productively conceptualize and enact a 'human security' vision of population management, how such a vision requires us to think differently and cooperatively about security, and ultimately how this compels us to supplant a prevailing narrative of external threat and risk with a story of shared precarity, human empathy and collective responsibility.

Keywords: European refugee crisis, human security, responsibility

John Morrissey, School of Geography and Archaeology, National University of Ireland, Galway, University Road, Galway H91 CF50, Ireland. E-mail: john. morrissey@nuigalway.ie

\section{Introduction}

Nick Gill's (2018) essay, 'The suppression of welcome', correctly calls out the impoverished logics and bureaucratic architectures of traditional statist security concerns. His piece is also abounding in hope and belief in the spirit of human empathy for the most marginalized in our societies. In sharing that hope, I want to take up a salient question he poses: "[t]o what extent can welcomers and welcoming initiatives be supported by international cooperation, global organisational and communication systems, and resource-gathering mechanisms?" (Gill 2018, 88). It is a key question, primarily because it signals the importance of transnational cooperation in dealing with a crisis that is transnational in scale. But within any transnational organisational framework lie states, and when we shift our focus from the 'state' to the 'transnational', we tend to invoke the import of global institutions in a way that frequently lets the state off the hook. We often fail subsequently in theorizing the effective implementation of cooperation, and in insisting upon the responsibilities to do so.

In responding to Nick's piece, I am wondering about a certain reluctance to call for the state and its various administrative structures and legal armatures to support and enact 'welcome'. An ongoing sustained critique of (neo)liberal state interventionary urges is important, for sure, but I think there may be more to be said in terms of state responsibilities, and the responsibilities of transnational, collective-state organisations such as the European Union (EU), towards human security and the protection of human rights for refugees and asylum seekers. To this end, I want to reflect here on how we might productively conceptualize a 'human security' vision of population management in a transnational context, which behoves us to think differently and cooperatively about 'security', and, crucially, to vigorously contest how its parameters are discursively defined and framed. 


\section{A crisis comes into view}

The current humanitarian crisis emanating from North Africa and the Middle East first came into mainstream view for Europeans and the rest of the world in 2015. The intensive media coverage of three-year old Alan Kurdi's tragic drowning in September of that year elevated international attention on the unfolding crisis in the Mediterranean Sea. Photographs of his little body washed up and so hauntingly alone on a Turkish beach were profoundly affecting and elicited a combination of outrage, empathy and calls for action. The outrage and calls for action were transitory, as is so often the case as media interest and public consciousness wanes. Glaringly missing too in the ensuing debates was any noteworthy self-reflexive critique of the crisis, particularly in terms of historicizing Western interventionary violence and the broader geopolitics of displacement across the Middle East and North Africa over the previous 15 years. Nonetheless, what became variously known as the 'European migrant crisis' or 'Mediterranean refugee crisis' brings into sharp focus the dreadful consequences of continued cyclical violence in our world today, and presents states across Europe with a common challenge: how to intervene responsibly in both support and mitigation; and, vitally, what instruments of policy we must enact to that end.

International human rights law (IHRL) and international humanitarian law (IHL) are designed to protect civilians, including refugees. Yet, the implementation of binding IHRL or IHL agreements has been a persistent challenge. The International Committee of the Red Cross refers to what it sees as an "institutional vacuum" in terms of implementation, and recently called for states across the globe to strengthen their capacities to implement their "obligations" (International Committee of the Red Cross 2015). 'Obligations' is a nebulous designation, of course. If there are little or no consequences to obligations not being met, then the implementation of protections will remain a tenuous objective. But, even more importantly, the absence of a vision for why the implementation of 'protections for all' actually benefits all is too often absent from political discourse. This is where a vision for 'human security' can aid us, I think, in terms of embracing an empathetic and ethical position on the most precarious in society, but also in adopting a collective and cooperative position on security - for all.

\section{A vision for human security}

In 1994, the United Nations Development Programme (UNDP) declared 'human security' as its primary global development goal. In the foreword to its Human Development Report that year, the UNDP's vision announced a "people-centred development" that set out a human security agenda for the $21^{\text {st }}$ century. It was security defined by "development, not arms", with a focal concern for "human life and dignity" (United Nations Development Programme 1994, iii, 1, 22). Human security, as the primary objective of locally-attuned interventionism, has been adopted across the Global South since 1994 by governments, transnational institutions, NGOs and community leaders (Elliott 2012). However, this new post-Cold War model of interventionism had limited impact in the Global North where old statist understandings of security have persisted. In fact, the 'hard' security issues of borders, bombs and bullets were emboldened under the auspices of the war on terror. In recent years, for example, the US model of interventionism in the Middle East led by the US military command, CENTCOM, has been underpinned by a traditional military-economic framing of security (Morrissey 2017).

As an academic working in geopolitics and international relations, I am all too familiar with the clinical and abstracted manner in which Western interventionism and military-economic security interests work. Typically, the profound human geographical consequences are out of view. The current refugee crisis in the EU has much to do with prior Western interventionism over the last half century or more on the borders of Europe, in the Middle East, Central Asia and North Africa. The effects of the last 15 years of pragmatic geopolitics are especially evident. Long-term refugees are a direct consequence and it is imperative to critically analyse the geopolitics of their displacement. In recent years, I have been trying to think about ways to insist upon broader visions of security, and this led me to the creation of an Irish Research Council project entitled 'Haven', which draws upon the UNDP's concept of 'human security' (Morrissey 2018). Haven is focused on Europe's response to the Mediterranean crisis, and has involved field research in France, Greece, Hungary and Ireland, an 
international symposium of academic, activist and NGO speakers and an edited book currently being completed for Edward Elgar Publishing.

The Haven book documents key dimensions of the crisis, including the legal mechanisms enabling or blocking asylum, the biopolitical systems for managing displaced peoples, and the multiple, overlapping historical precedents of today's challenges. The book and the broader project is about presenting an alternative 'human security' envisioning of Western interventionism that critiques the kinds of military and economic definitions of security that commonly involve recurring mechanisms of governmental violence and clinical regimes of population management. Human security calls for investing in, and resourcing, interventions of a different kind: in protecting human rights; in insisting upon humanitarian law; in supporting civil society; and in enabling locally-attuned rather than toptown security measures.

Crucially, human security involves a mobilisation of the law in coalescing human rights concerns with a human security vision, as detailed by Estrada-Tanck (2016). Such a vision speaks in multiple ways to the current ad hoc security system of camps, holding centres and direct provision measures in the European Union (EU) - from Ireland to Greece. The human security paradigm advanced and supported by the UN places particular emphases on legally-binding human rights law, which challenges governments across the EU to take responsibility for, and think cooperatively about, a more collective and sustainable sense of security. We need to pay attention, of course, to the selective invocation and use of the law, which governments across the Global North, in particular, have become adept at in recent years - both in terms of violent military interventions and humanitarian responses to crises (Morrissey 2015). In showing how "procedures for registering, assessing, protecting and managing refugees rework the trauma of war and violence", Loyd, Erkampt and Secor have outlined how refugees in Turkey are "caught in a prolonged limbo, during which they are subject to layers of bureaucracy, repeated interviews and ongoing demands to prove their deservingness" - and all of this is happening "within the international humanitarian logic that governs their access to care and resettlement" (Loyd et al. 2018, 377, 386).

\section{The discursive battle for 'security'}

Current state mechanisms of refugee population management across the EU divulge an impoverished security thinking and strategy. The focus on 'risk' is instructive, as it legitimates the so-called exceptional management of individuals who are not citizens and therefore not deserving of our care. Their vulnerabilities are neither recognized nor acknowledged. Instead, refugees are typically presented as a threat and the source of insecurities, rather than their consequence - further serving to reinforce the appropriateness of biopolitical governmental measures to manage such threats, and in a manner that is out of sight and out of mind. A fundamental and vital discursive challenge is to render visible precarity, and to foreground a story of vulnerability in the place of narratives of risk. This is where a human security conceptualisation can aid us. Such a goal involves an old postcolonial concern, of course: enabling the subaltern, the marginalized to speak - those whose lives, homes and worlds have been wrecked and displaced by relentless interventionary violence, always in the name of a particular type of 'security'.

The prevailing statist understanding of security across the EU is mirrored in the overwhelming predominance of instrumental and technocratic research calls on security and migration supported by current EU funding. Faced with this monopolisation of how security is defined and what its concerns are, we need to increasingly and collectively advocate for a broader human security agenda, supporting research that brings together scholars, policy makers, activists and (crucially) refugees themselves, in creatively considering how to respond responsibly to what is one of the most pivotal 'societal challenges' for the EU since its formation. Such a plea ties in with the important concerns raised by earlier responses to Nick's piece here in Fennia, about being attentive to the conditions of how we are expected to do and measure 'societal impact' in an age fixated with metrics and economized values (Bagelman 2018; Vainikka \& Vainikka 2018).

There is a need too to refuse and challenge how the media and many political parties across Europe negatively portray migration and its effects. We must insist upon and successfully distil more humane, 
nuanced and historically and geographically sensitive accounts of the crisis, which resist the allure of simplified responsive logics of walls, borders and separations of 'us' and 'them'; and we need to increasingly do this via engaged public scholarship, especially in an era of post-truth politics.

\section{Conclusion}

The picture of how EU citizens view and welcome refugees is not straightforward. Vuolteenaho and Lyytinen are correct to point out that there are "ambiguous and contextually varying attitudes to (un) welcoming immigrants" $(2018,118)$. No doubt too, the "quizzical looks, the questions, the hesitation and disquiet" towards 'outsiders' will continue from various quarters (Norum 2018, 116). But how do we build upon what Gill $(2018,88)$ cites as a grassroots majority who believe that "their governments should do more to help refugees"? And how do we remember, as Sparke $(2018,216)$ so usefully puts it, that the "in-between spaces of welcome are in constant danger of being overwhelmed by the forces of suppression"?

I have argued here that a key starting point in advancing welcome and support for refugees is the collective envisioning of a 'human security for all', which negates simplified and populist arguments that divisively separate out 'us' and 'them'. A human security agenda for dealing with the Mediterranean refugee crisis requires a careful and repeated documenting of the precarious and marginalized worlds of forced migrants across the EU. It necessitates bringing such worlds into view. It also must involve critique beyond the academy and support for a politics of solidarity with an 'Other' rarely seen. Thinking through how to strategize for, and enact, a people-centred security for all is not straightforward, but it is not impossible. A critical responsibility lies with the EU in setting out and tasking individual member states to meet an agreed obligation to support a collective sense of security, inspired by a human security vision. This might be admittedly difficult to imagine given the current ubiquity of statist understandings of security across the EU, but prevailing discourses of security have always centrally involved shaping what the security problem is deemed to be - and by extension the response. In other words, defining security and acquiring resources for the kind of 'security solution' deemed necessary is paramount. Recognising this compels us to formulate and communicate coherent and compelling narratives about the kind of security we all want - for whom and from what.

Human security, as both a discourse and an interventionary strategy, can aid us in considering complicated questions of displacement, migration, human rights and humanitarian responsibility. It can conceptualize the intricacies of the challenges faced and it can also build a politics of solidarity in working solutions that call out the failure of top-down, technocratic security measures and herald instead the success and hopes of locally-attuned, people-centred interventions. Human security is ultimately about envisioning shared precarity, interlinked risk and cooperative security responses for all.

\section{Acknowledgements}

My thanks to Kirsi Pauliina Kallio and James Riding at Fennia for their intellectual vision and editorial support in facilitating a broadened conversation on Nick Gill's important intervention.

\section{References}

Bagelman, N. (2018) Who hosts a politics of welcome? - commentary to Gill. Fennia 196(1) 108-110. https://doi.org/10.11143/fennia.70294

Elliott, L. (ed.) (2012) Climate Change, Migration and Human Security in Southeast Asia. Rajaratnam School of International Studies, Singapore. https://doi.org/10.4324/9780203107775

Estrada-Tanck, D. (2016) Human Security and Human Rights under International Law: The Protections Offered to Persons Confronting Structural Vulnerability. Hart Publishing, Oxford.

Gill, N. (2018) The suppression of welcome. Fennia 196(1) 88-98. https://doi.org/10.11143/fennia.70040

International Committee of the Red Cross (2015) Meeting of States on strengthening compliance with international humanitarian law. International Committee of the Red Cross < www.icrc.org/en/ document/meeting-states-strengthening-compliance-international-humanitarian-law>. 30.10.2018. 
Loyd, J. M., Secor, A. J. \& Ehrkamp, P. (2018) A geopolitics of trauma: refugee administration and protracted uncertainty in Turkey. Transactions of the Institute of British Geographers 43(3) 377-389. https://doi.org/10.1111/tran.12234

Morrissey, J. (2015) Securitizing instability: the US military and full spectrum operations. Environment and Planning D: Society and Space 33(4) 609-625. https://doi.org/10.1068/d14033p

Morrissey, J. (2017) The Long War: CENTCOM, Grand Strategy, and Global Security. University of Georgia Press, Athens (GA).

Morrissey, J. (2018) Haven: Intervening for human security. Irish Research Council <havenprojectblog. wordpress.com>. 30.10.2018.

Norum, R. (2018) From welcome to well ... come: the mobilities, temporalities and geopolitics of contemporary hospitality - commentary to Gill. Fennia 196(1) 111-117. https://doi.org/10.11143/ fennia.70403

Sparke, M. (2018) Welcome, its suppression, and the in-between spaces of refugee sub-citizenship commentary to Gill. Fennia 196(2) 215-219. https://doi.org/10.11143/fennia.70999

United Nations Development Programme (1994) Human Development Report 1994: New Dimensions of Human Security. Oxford University Press, New York.

Vainikka, V. \& Vainikka, J. (2018) Welcoming the masses, entitling the stranger - commentary to Gill. Fennia 196(1) 124-130. https://doi.org/10.11143/fennia.70227

Vuolteenaho, J. \& Lyytinen, E. (2018) Reflections on the variations and spatialities of (un)welcome commentary to Gill. Fennia 196(1) 118-123. https://doi.org/10.11143/fennia.70290 